\title{
MIDWIFE ACCOUNTABILITY IN MANAGING MIDWIFERY CARE AT BIDAN PRAKTEK MANDIRI OF BANDUNG REGENCY
}

\author{
Sri lestariKartikawati*1, Sismeri Dona ${ }^{2}$ \\ \{ sri.lestari@bku.ac.id ${ }^{1}$, sismeridonas2keb06@gmail.com\} \\ ${ }^{1}$ Departemen of Midwifery, faculty of health Universitas Bhakti kencana, Bandung, \\ ${ }^{2}$ Departement of midwifery, faculty of health, Universitas Sari Mulia Banjarmasin \\ *Corresponding author: sri.lestari@bku.ac.id
}

\begin{abstract}
Midwifery documentation is the recording and reporting of midwifery as a form of accountability for midwifery care that has been performed. All midwife actions must be performed based on competence and a clear legal basis so that the bias can be calculated. The purpose of this study was to determine the accountability of midwives in the management of midwifery care documentation at Bidan Praktek Mandiri of Bandung Regency by using a qualitative approach. Based on observations and deep interviews, it can be concluded that the midwives accountability in managing midwifery care documentation is still not optimal yet.
\end{abstract}

Keywords. Accountability, Documentation, Midwifery Services

\section{Introduction}

Midwifery documentation is an evidence of recording and reporting based on accurate and complete written communication that is owned by midwives in performing midwifery care and is useful for the benefit of clients, health teams, and themselves $[1]$.

Responsibility and accountability of the profession is one of the reasons for holding midwifery documentation in midwifery service. Documentation is part of midwife activities after providing midwifery care. Through this documentation, it is hoped that there will be no care plans that are not performed at all and midwives are able to minimize the errors in her duty. Information in midwifery documentation can be used in case of malpractices which involve midwifery care. Documentation can be important in determining whether midwifery care meets the standards or not [1].

The results of the documentation that performed by the midwife were reported as proof of accountability of Bidan Praktek Mandiri as a health worker with the type of report in accordance with the Minister of Health Regulation of the Republic of Indonesia No. 28 of 2017 concerning Licensing and Organization of Midwife Practices.

In the regulation of Health Minister No.28 of 2017 concerning licensing and organization of midwife practices chapter $\mathrm{V}$ article 45 concerning recording and reporting. Midwives must record and report their activity according to the services provided.

The services provided include Antenatal Care (ANC), Intranatal Care (INC), Postnatal Care (PNC), Newborn and Babies, Family Planning and Emergency Care for Mothers or Babies. The services provided must be recorded in full to improve the continuity of care for patients, and strengthen the accountability (responsibility) of midwives in implementing and 
evaluating services provided and helping institutions to meet the requirements of requirements[2].

It will lead the problem for patients if there is no documentation and health status of the patient is not monitored. If the midwife does not perform or complete an activity or document incorrectly, the can be sued for malpractice activity.

Midwifery documentation must be legally reliable, i.e. it must provide accurate reports about the care received by patients [2]. If the midwife does not perform the documentation, it will have an impact on the work area which is not recording public health status so that the number of occurrences in the midwifery process is unrecognized. The importance of documentation reporting is to extend the STR (Registration Certificate) for conducting midwifery service activities.[3].

Preliminary studies that conducted at the Indonesian Midwives Association of Bandung Regency found that the number of midwives in Bandung Regency in 2018 was 1046 people with a total of 98 Bidan Delima. Based on the results of interviews with the head of IBI Bandung, the problems arise is that the non compliance of the midwife in reporting the documentation, they ignorance it and non-socialized the activities. The survey at 5 midwives of Public Health Centre in Bandung Regency found 2 people who did not complete the full monthly report of childbirth and neonatal services. Midwives are required to report their services every month to the public health centre and complete the documentation. The objective of the research is to find out the accountability of midwives in managing midwifery documentation in Bidan Praktek Mandiri in Bandung Regency in 2018.

\section{Material and Method}

The approach used in this research is descriptive qualitative approach. Data collection used is in-depth interviews. Data analysis is by reducing, presenting and verifying data

\section{Result}

The results on the accountability of midwives in managing midwifery documentation in Bidan Praktek Mandiri of Bandung Regency can be seen from the completeness of the documentation content that includes reviewing, diagnosing or assessing data, and implementing and evaluating.

According to the informants, the format of midwifery care documentation has a different form. Based on observations it is known that the form consists of an assessment form having a checklist format and a short entry. Whereas for diagnosis or assessment data is provided in accordance with the problems and patients needs so that the midwife just adjusts to the patient's condition. For the diagnostic form or assessment data, researchers found that the format was in the form of entries. For the implementation and evaluation forms, the format is in the form.

In filling it out the form, some informants thought that there was no difficulty in filling it. It's just that during this time constrained by the limited time so that resulted in delaying filling the form. This was stated by the informant as follows:

"If it is difficult, maybe not, only during very busy times such as labor, the condition of emergency patients sometimes likes to forget to fill or be filled but it's short ..." (Informant 3) 
"For example, for a full assessment like this, I don't think it's enough for 15 minutes or half an hour. That is not yet another action. If for example we hold one patient a day yes maybe still can. If for example there are a lot of patients, one needs what one needs, it won't be covered ... "(Informant 5)

"No ... it's just that sometimes that's the length of our documentation, sometimes if for example our actions take precedence over documentation. Yes that's possible maybe we need extra time ... "(Informant 4)

Other facilities that support the documentation of midwifery care are the standards set forth in Decree of the Minister of Health of the Republic of Indonesia Number 938 / Menkes / SK / VIII / 2007 concerning Midwifery Care Standards. Midwifery care standards are a reference in the decision making process and actions taken by midwives in accordance with the authority and scope of practice based on midwifery knowledge and tips. Starting from the assessment, formulation of diagnoses and / or obstetric problems, planning, implementation, evaluation and recording of midwifery care. However, technical instructions for filling in the documentation of midwifery are recognized as not yet available as disclosed by the informants as follows:

"We don't have any written technical guidelines yet. I don't think so. "(Informant 1)

"If I filled in the technical guidelines, I don't know whether or not there. Maybe it might not exist but if I myself and some we are given the information if the filling if it's not a problem we still fill it no problem .. "(Informant 2)" The book itself is not yet available, technical instructions, if for example there is usually usually limited So, what kind of technical guidelines do we have? "(Informant 3)

"Oohh, there are guidelines, if the guidelines for how to fill it, I have never held it ..." (Informant 4) "For the filling guide, oo is not there yet. Make it like that ... "(Informant 5)

Based on observations by looking at the completeness of midwifery care documentation seen from the presentation, diagnosis, management and evaluation, it is known that the completeness of midwifery care documentation in pregnancy is as many as $46 \%$, documentation of midwifery care in labor reaches as many as $60 \%$, documentation in postpartum mothers reaches as many as $42 \%$, documentation on BBL \& infants accounted as many as $48 \%$, documentation of family planning midwifery reached as many as $38 \%$, documentation in the emergency department reached as many as $70 \%$. It can be concluded that the completeness of midwifery care documentation (at the time of the study) only reached as many as $63 \%$. For more details, the documentation of midwifery care can be seen in the table below:

Table 1. Completeness of Midwifery Care Documentation in Bidan Praktik Mandiri of Bandung

\begin{tabular}{lcccc}
\hline Variable & \multicolumn{2}{c}{ complete } & \multicolumn{2}{c}{ incomplete } \\
& $\begin{array}{c}\text { Freq } \\
\text { uency }\end{array}$ & \% & \multicolumn{2}{c}{ Frequ } \\
ency & \% \\
\hline Antenatal documentation & 23 & 46 & 27 & 54 \\
Intranatal documentation & 30 & 60 & 20 & 40 \\
Postnatal documentation & 21 & 42 & 29 & 58 \\
Newborn documentation & 24 & 48 & 26 & 52 \\
Family $\quad$ planning & 19 & 38 & 31 & 62 \\
documentation & & & & 30 \\
Maternal and neonatal & 35 & 70 & 15 & \\
emergency documentation & & & & \\
\hline
\end{tabular}


Regency Midwives

\section{Discussion}

The results showed that the average documentation of midwifery care was incomplete. Most midwives do not fill in the documentation in the anamnesa result (with the reason the patient said that there were no complaints so the midwife did not fill in the anamnesa data completely). Objective data only filled in important data only. The midwife's diagnosis section did not write in complete and was not accompanied by problems and needs, and management is not accompanied by evaluation. All aspects in the documentation are very important to be filled in and completed considering that there is a lot of information that must be conveyed in the documentation both information for other health workers who need it or if at any time is needed for legal purposes. Documentation of midwifery care needs to do a complete documentation because it can be used as material to account for actions taken and also if there is a lawsuit, the midwifery documentation can help midwives as health workers and the implementation of midwifery care.

Midwives must record and report according to the services provided. Documentation in midwifery is a proof of recording and reporting possessed by midwives in carrying out treatments that are useful for the benefit of clients. According to Permenkes RI No.269 / MENKES / PER / III / 2008 concerning Medical Records Chapter II article (3) concerning the contents of medical records include: Patient identity; date and time; history results; includes at least complaints and history of disease; physical examination and medical support results; diagnosis; management plan; and treatment and / or action[2].

As for the case of emergency, this documentation is very important to provide information on the place of reference matters relating to the patient's condition. According to the legal aspect, if the service that has been provided is not documented, it means that the responsible party is not doing what is supposed to be done. the contents of this documentation are important relating to the existence of a lawsuit of patient dissatisfaction with services related to legal aspects, so the documentation that is filled out completely and correctly can be used to respond to dissatisfaction with services received legally $[4,5]$.

The results showed that the implementation of midwifery documentation in Bidan Praktek Mandiri was not in accordance with the Midwifery Care Standards set by the Minister of Health. Midwives' ability in documentation is aimed at writing skills in accordance with consistent documentation standards, effective, complete, and accurate patterns.

Regarding to the limited time complained by midwife informants to document midwifery care. This cannot be used as a reason for incomplete documentation of midwifery care. Because documentation is not only done at a certain time, it can be done continuously or continuously (on going assessment) which is re-documentation that is done again after the initial assessment to strengthen and expand the basic data that has been obtained. Patience is required in making documentation of midwifery care, including taking time to check the truth of patient data that has been or is being examined $[4,5]$. 



\section{Reference}

[1]. Hidayat. Metode Penelitian Keperawatan dan Tekhnik Analisis Data. Jakarta: Salemba Medika. [2009].

[2]. Kemenkes RI. Profil Kesehatan Indonesia. Jakarta: Kemenkes RI. [2017].

[3]. IBI. Panduan Pengorganisasian: Program Bidan Delima; Buku Pelatihan Fasilitator Bidan Delima: BukuAcuan; Instrumen Instrumen Validasi: Program Bidan Delima. [2018].

[4]. Wahyuana, Priyo. AnalisisVariabel Yang Berhubungan Dengan Pendokumentasian Asuhan Keperawatan di RS Krakatau Cilegon Tahun 2011. Depok : Program Pasca Sarjana Kesehatan Masyarakat Fakultas Kesehatan Masyarakat Universitas Indonesia. [2011].

[5]. Widyaningtyas, Khristina Setya. Analisis Faktor-Faktor Yang Mempengaruhi Kepatuhan Perawat Dalam Pendokumentasian Asuhan Keperawatan. [2007]. 